\title{
Sub-National Government and the Problem of Unequal Development in ASEAN Economic Integration: Case of Indonesia*
}

\author{
Agus Suman \\ Pantri Muthriana Erza Killian \\ Ni Komang Desy Arya Pinatih
}

\author{
University of Brawijaya, Indonesia \\ University of Brawijaya, Indonesia \\ University of Brawijaya, Indonesia
}

\begin{abstract}
Economic integration, as a prevalent phenomenon in contemporary international relations, brings with it several problems including in the practice of development. Krapohl $\mathcal{E}$ Fink (2013) argue that regional integration can follow three different developmental paths which are intra-regional interdependence, extra-regional dependence and intra-regional asymmetries and hence regional integration can in fact reinforce current situations rather than changing it. With regards to this, ASEAN is following the second path, creating a reliance on external actors and thus requiring member states to be highly competitive in the global level. However, this strategy ignores an important element, the intra-national development gap, since ASEAN is mostly focused in overcoming the intra-regional gap. This paper therefore seeks to elaborate the problem of increasing intra-national development gap due to regional integration by using Indonesia as a case study. The findings show that regional integration in Indonesia can in fact widen the national development gap due to three main reasons. First, ASEAN integration is highly top-down in nature, thus limiting the role of Indonesia's sub-national governments (SNGs) and private actors in the process; second, differing capacity of Indonesia's sub-national governments to engage in IR provides higher opportunities for some while creating hindrances for others and lastly, the high transactional cost of intra-national economic activities in Indonesia causes the benefits of economic integration to be highly concentrated in one area. Therefore, there needs to be a larger role for SNGs in regional integration particularly in the most underprivileged area of Indonesia.
\end{abstract}

Key words: ASEAN, Indonesia, development gap, sub-national government

- This article was originally presented in The Fourth International Conference on Business, International Relations, and Diplomacy (ICOBIRD 2015) at Bina Nusantara University. 


\section{Introduction}

For most countries, regional integration is no longer a choice but a necessity. The need to be included in the global economy and obtain the benefits of a freer market have forced countries to engage in multiple trade arrangements. As of April 2015, a total of 612 regional trade agreements have been reported to World Trade Organization, with 406 agreements being in force (WTO, 2015). Of these 406 agreements, there are at least 13 arrangements which are formed based on regional integration or regionalism. By far, European Union (EU) is the most advanced regional integration while Association of Southeast Asian Nations (ASEAN) is the most successful and longenduring regional integration outside of the western world (Beeson, 2013).

ASEAN member countries themselves are highly diverse in terms of economic growth and political conditions. Its member countries include wealthy states such as Singapore and democratic countries like Indonesia, but also incorporate poor countries such as Cambodia and authoritarian states like Myanmar. In terms of economic growth, intra-ASEAN trade has a moderate growth, with an average growth of 7.62 per cent from 2007 up to 2013 (ASEAN Statistical Yearbook, 2014). This number is relatively low compared to other areas such as Europe and Southern America. At the end of 2015, ASEAN will enter a higher level of economic integration which includes free flow of labor, investment and capital, commonly known as ASEAN Economic Community. Under this scheme, one of the main goal or pillar is to achieve an 'equitable economic development' which focuses on minimizing development gap between member countries. However, aside from development gap among member countries, ASEAN is also facing development gap within their own countries, such as the case of Indonesia.

$$
\text { Indonesia is an archipelagic }
$$
country with a relatively modest infrastructure quality and a high level of inequality. Indonesia has one of the fastest growing inequality rate (Gini index) in East and Southeast Asia, rising from 0.32 in 1999 to 0.41 in 2012 (World Bank, 2014a). Indonesia's inequality is not only evident in the fact that Indonesia's richest population has enjoyed a 20 per cent higher growth in their income and consumption since 2003, but also a disparity in regional development progress where eastern Indonesia lags in other areas (World Bank, 2014). According to the head of Indonesia's Autonomy Watch or KPPOD, Sofjan Wanandi, only 10 per cent of Indonesian cities experienced an improvement in their economic performance ever since Indonesia's implementation of a decentralization policy in 2001 (Antique, 2009).

Based on this background, this paper seeks to explain ASEAN regional integration and its effect on development, particularly on intra-national inequality, by using Indonesia as the case study. This paper argues that when regional integration is implemented in a country with high level of economic inequalities, its benefits will be diminished since regionalism will in fact widen the development gap, as in the case of Indonesia. Furthermore, the nature of the integration, whether it is a top-down or bottom-up integration, also determines the effect of regionalism on development, since it can lead to a concentration of power and rulemaking capacity at the central government. This paper will be 
divided into three parts where part one will review existing studies of regionalism and sub-national government while part two and three will discuss regional integration in Indonesia and highlight the role of sub-national government in this process.

\section{Theorizing Economic Integration and Regionalism}

Economic integration is the removal of barriers to trade, payment and mobility from the factors of production, or in other words, is an effort to unite the economies of two or more countries through a series of joint policies (Carbaugh, 2010). Basically, the idea of economic integration dates back to liberal economists such as Adam Smith and David Ricardo who believe that nonrestricted economic activities will give the most efficient outcome for all countries. Economic integration will create static efficiency gains and dynamic efficiency gains (Balaam \& Dillman, 2011). Static efficiency gains occur because economic integration will lead to specialization among member countries and market expansion, resulting in the economies of scale (Balaam \& Dillman, 2011). Aside from static efficiency gains, economic integration will also bring dynamic efficiency gains because in the long run, economic integration will stimulate innovation and make industries much more efficient and competitive (Balaam \& Dillman, 2011). Although, economic gain was often considered the primary motive for regional integration, newer theories of regionalism focus less on highlighting only the economic gains.

In general, theories of regionalism can be classified into 2 eras or waves of theorizing, the classical theories and the new waves or New Regionalism Approach (NRA). Classical theories which range from 1960s to 1980s focus mostly on the debate between the intergovernmental and supranational approach, which highlights the difference between regionalism as an inter-state project and regionalism as a project to create institutions above the state (supranational). Theories under this heading include classic theories of functionalism, neofunctionalism, federalism, confederalism and liberal intergovernmentalism. Newer theories of regionalism emerge in the late 1980s and early 1990s following the shift and inclusion of non-material or ideational factors in the analysis. One important theory under the New Regionalism Approach is Multilevel Governance (MLG) in which the article uses as its basis.

Marks (1996) defines MLG as a policy-making or decision-making process which involves not only the state as the exclusive actor but also other actors at various levels, namely at the supranational, national and sub-national levels. Under MLG, each level should have the authority to create and implement policies and in several cases, to even refuse in implementing decisions that higher levels of authority impose. Multilevel governance was originally developed in the European Union where the tendency to result in overlapping governance among multiple levels of government is high since many countries uses a decentralized system of government. MLG tries to avoid this problem by offering an alternative form of power sharing between multiple levels of governance and reduces the chances of overlapping. Multilevel governance sees regionalism as a process of governance and policy making that involve multiple actors at multiple levels (supranational, national and sub-national), employing both vertical and horizontal relationship 
(Gavin, 2005). Horizontal relationship means that the process involves multiple actors at the same level while vertical relationship involves different levels of governance (Gibson, 2011). In this sense, MLG expands the classic definition of rulemaking (in terms of regional integration) by government to include various actors at multiple levels.

\section{Regionalism and Development in ASEAN Countries}

In their 2007 Report, United Nations Conference on Trade and Development (UNCTAD) stated that developing countries have started to use regionalism as one of their development strategies since it is viewed as a collaborative effort that countries do to engage in development. However, countries are also in a dilemma on choosing to fully integrate themselves to the global economy or still trying to retain their economic sovereignty. Hence, countries are struggling to balance their domestic interests, regional agreements and international demands through multilateral cooperation (Abugattas, 2004). With regards to ASEAN, relatively low socio-economic conditions by member countries has caused development to be one of the priority issues in ASEAN.

Table 1. Human Development Index (HDI) of ASEAN Member Countries

(1985-2013)

\begin{tabular}{|l|c|c|c|c|c|c|c|c|}
\hline \multicolumn{1}{|c|}{ Country } & \multicolumn{1}{|c|}{1985} & 1990 & 2005 & 2008 & 2010 & 2011 & 2012 & 2013 \\
\hline \multicolumn{1}{|c|}{$(1)$} & \multicolumn{1}{c|}{$(2)$} & $(3)$ & $(4)$ & $(5)$ & $(6)$ & $(7)$ & $(8)$ & $(9)$ \\
\hline Brunei Darussalam & - & 0.786 & 0.838 & 0.843 & 0.844 & 0.846 & 0.852 & 0.852 \\
Cambodia & - & 0.512 & 0.536 & 0.564 & 0.571 & 0.575 & 0.579 & 0.584 \\
Indonesia & 0.582 & 0.623 & 0.640 & 0.654 & 0.671 & 0.678 & 0.681 & 0.684 \\
Lao PDR & 0.422 & 0.449 & 0.511 & 0.533 & 0.549 & 0.560 & 0.565 & 0.569 \\
Malaysia & 0.693 & 0.720 & 0.747 & 0.760 & 0.766 & 0.768 & 0.770 & 0.773 \\
Myanmar & - & - & 0.472 & 0.500 & 0.514 & 0.517 & 0.520 & 0.524 \\
Philippines & 0.692 & 0.719 & 0.638 & 0.648 & 0.651 & 0.652 & 0.656 & 0.660 \\
Singapore & 0.784 & 0.821 & 0.840 & 0.868 & 0.894 & 0.896 & 0.899 & 0.901 \\
Thailand & 0.673 & 0.705 & 0.685 & 0.704 & 0.715 & 0.716 & 0.720 & 0.722 \\
Viet Nam & 0.582 & 0.610 & 0.598 & 0.617 & 0.629 & 0.632 & 0.635 & 0.638 \\
\hline
\end{tabular}

Source: ASEAN Statistical Yearbook (2014)

In average, there has been an increase in the human development condition of ASEAN member countries from the year of 1985 up to 2013, with Lao PDR obtaining the lowest HDI (0.569) and Singapore has the highest (0.901). The difference between Singapore and Lao
PDR is around 0.4 which shows quite a high level of human development inequality. In addition to that, the domestic inequality also shows a similar picture. 
On average, from 1990-2013 almost all ASEAN countries have the experience of an increase in their Gini coefficient, with Indonesia showing the steadiest upward trend. This shows that despite the implementation of ASEAN Free Trade Area in 1994, domestic inequality remains a large problem in Southeast Asia. In terms of intra-ASEAN trade itself, ASEAN still trade largely with external countries (non-ASEAN states) with a ratio of around 1:3, in both exports and imports (ASEAN Statistical Yearbook, 2014).

Table 2. Gini Coefficient of ASEAN Member Countries (1990-2013)

\begin{tabular}{|l|r|r|r|r|r|r|r|r|r|r|r|}
\hline \multicolumn{1}{|c|}{ Country } & \multicolumn{1}{|c|}{1990} & 2000 & 2005 & 2006 & 2007 & 2008 & 2009 & 2010 & 2011 & 2012 & 2013 \\
\hline \multicolumn{1}{|c}{$(1)$} & \multicolumn{1}{c|}{$(2)$} & \multicolumn{1}{c|}{$(3)$} & $(4)$ & $(5)$ & $(6)$ & $(7)$ & $(8)$ & $(9)$ & $(10)$ & $(11)$ & $(12)$ \\
\hline Brunei Darussalam & - & - & - & - & - & - & - & - & - & - & - \\
Cambodia & $0.380^{1)}$ & $0.351^{3)}$ & 0.419 & - & 0.444 & 0.379 & 0.360 & - & - & - & - \\
Indonesia & 0.320 & $0.310^{3)}$ & 0.343 & 0.357 & 0.360 & 0.350 & 0.370 & 0.380 & 0.410 & 0.410 & 0.413 \\
Lao PDR & - & - & - & 0.354 & - & 0.367 & - & - & - & - & - \\
Malaysia & 0.442 & $0.443^{3)}$ & 0.379 & - & 0.441 & - & 0.462 & - & - & - & - \\
Myanmar & - & - & - & - & - & - & - & - & - & - & - \\
Philippines & $0.468^{2)}$ & 0.488 & 0.440 & 0.458 & - & - & 0.464 & - & - & - & - \\
Singapore & - & - & - & - & 0.482 & 0.474 & 0.471 & 0.472 & 0.473 & - & - \\
Thailand & 0.524 & 0.525 & 0.425 & 0.418 & 0.397 & 0.401 & 0.396 & 0.394 & - & - & - \\
Viet Nam & - & - & 0.378 & 0.420 & - & 0.434 & - & 0.433 & - & - & - \\
\hline
\end{tabular}

Source: ASEAN Statistical Yearbook (2014)

\section{Regionalism and Sub-National Government: Case of Indonesia}

In terms of the formation of regionalism, ASEAN is considered as highly state-centric in nature. ASEAN Secretariat (ASEC) only acts as the facilitator for member states' activities. ASEC is also understaff and has no executive or legislative power (Wunderlich, 2012). Furthermore, ASEAN member countries deliberately avoid creating a strong supranational institution, making ASEAN Secretariat highly underpowered (Hill \& Menon, 2010). In contrast to EU which is highly supranational, ASEAN limits rulemaking ability and involvement of other sectors other than the central government. In supranationalism, regionalism is usually a result of complex interactions between different actors at various political levels. Supranational institutions can also be a medium for society to advance their own interests with less government involvement. A study by Guido \& Kamarulnizam (2011) shows that although Indonesian public generally supports the ASEAN Community, they lack the knowledge regarding its process and policymaking which means that the process excludes them greatly. However, this is not to say that ASEAN's intergovernmental is less favorable that EU's supranationalism since ASEAN offers flexibility that EU does not always have. All in all, although state-centric regionalism is not necessarily bad, it can generally reduce the public's awareness 
and involvement in the overall process, particularly those who are marginalized.

\section{Aside from ASEAN's} characteristics, Indonesia also faces a problem in provincial disparity at various economic sectors, such as trade and investment. In terms of foreign trade, data shows that Indonesia has average export growth of 1.59 per cent in non-oil and non-gas sector (Ministry of Trade, Republic of Indonesia, 2015). However, 18 provinces (out of 32 provinces) records a lower growth rate than the average rate as well as 17 provinces experiencing a decline in export growth (Indonesian Ministry of Trade, 2015). In terms of investment, foreign investments are also mostly dominated in Java area particularly in DKI Jakarta, West Java and Banten (BPS-Statistics Indonesia, 2015). One exception is for East Kalimantan province that records a high amount of foreign investment. This disparity attributes to the fact that Indonesia has a large gap in terms of conducting international trade and attracting investment. Not all provincial or city government are equipped with the ability to create, promote, communicate or engage in foreign activities due their limited human resources. This in turn creates limitation for them to reap the benefits of freer trade and investment flows. This situation is also worsened by the high transactional cost between provinces in Indonesia.

The high cost of domestic trade is one element that can reduce Indonesia's competitiveness at the global level (Asia Foundation, 2008). It is reported that Indonesia's cost of transporting goods is around USD 0.34 per kilometer which is higher than Asia's average cost at USD 0.22 per kilometer (Asia Foundation, 2008). This high logistics cost results in a price difference of 20-100 per cent between western and eastern Indonesia. For example, a sack of cement can cost 10 times more in eastern Indonesia than it is in the western area (Pambudy, 2011). Under this condition, competitiveness will also vary greatly between provinces in Indonesia since provinces which have access to international ports will be more competitive. Tanjung Priok port in Jakarta (Indonesia's capital) currently accounts for two-thirds of Indonesia's international trade (World Bank, 2014b) meaning that only one-third of Indonesia's international trade is done outside of the capital city. This shows that international trade is still highly concentrated in the wealthiest area.

\section{Conclusion}

Based on the discussion, it can be viewed that despite the implementation of decentralization, problem of inequality in Indonesia still exists (as is shown by Gini Index). With regards to economic integration in Southeast Asia, positive effects of ASEAN economic integration to reduce intra-state inequality is still not present. The implementation of ASEAN Free Trade Area in 1994 does not translate to reduced inequality and on the contrary, increases inequality. For Indonesia, the biggest problem is the high discrepancy between provinces and the limited capacity of provincial and city government. With limited capacity to engage in productive international relations, these cities and provinces may lose their opportunity to benefit from the economic integration under ASEAN's scheme.

\section{About the Authors}

Agus Suman is a lecturer at Department of International Relations, 
Faculty of Political and Social Sciences, University of Brawijaya.

Pantri Muthriana Erza Killian is a lecturer at Department of International Relations, Faculty of Political and Social Sciences, University of Brawijaya.

Ni Komang Desy Arya Pinatih is a lecturer at Department of International Relations, Faculty of Political and Social Sciences, University of Brawijaya.

\section{References}

Antique, P., \& Rini, E. S. (2009, August 13). Otonomi daerah picu pertumbuhan daerah turun. Retrieved October 24, 2015 from Vivanews: http://bisnis.news.viva.co.id/news/ read/82675/otonomi daerah picu pertumbuhan daerah turun.

Association of Southeast Asian Nations Seretariat. (2014). ASEAN Statistical Yearbook 2014. Jakarta: ASEAN Secretariat.

Badan Pusat Statistik. (2015). Foreign direct investment realization by province. Retrieved October 25, 2015, from Badan Pusat Statistik: http://www.bps.go.id/linkTabelSta tis/view/id/1337.

Balaam, D. N., \& Dillman, B. (2011). Introduction to international political economy (5th ed.). Boston: Longman.

Beeson, M. (2013). Living with giants: ASEAN and the evolution of Asian regionalism. TRaNS: Trans-Regional and-National Studies of Southeast Asia, 1(2), 303-322.

Benny, G., \& Abdullah, K. (2011). Indonesian perceptions and attitudes toward the ASEAN
Community. Journal of Current Southeast Asian Affairs, 30(1), 39-67.

Carbaugh, R. J. (2005). International economics (10th ed.). Mason, Ohio: Thomson/South-Western.

Gavin, B. (2005). Reconciling regionalism and multilateralism: Toward multilevel governance. Bruges: UNU Institute on Comparative Regional Integration Studies.

Gibson, R. (2011). A primer on collaborative multilevel governance. Ontario: Canadian Regional Development.

Hill, H., \& Menon, J. (2010). ASEAN economic integration: Features, fulfillments, failures and the future. ADB Working Paper Series on Regional Economic Integration, 69.

Hooghe, L., \& Marks, G. (2002). Types of multilevel governance. Les Cahiers Europeens de Sciences Po, 03. Paris: Centre D'etudes Europennes at Sciences Po.

Krapohl, S., \& Fink, S. (2013). Different paths of regional integration: Trade networks and regional institution-building in Europe, Southeast Asia and Southern Africa. JCMS: Journal of Common Market Studies, 51(3), 472-488.

Majluf, L. A. (2004). Swimming in the spaghetti bowl: Challenges for developing countries under the new regionalism. New York and Geneva: United Nations.

Ministry of Trade Republic of Indonesia. (2015). Growth of non-oil and gas export: Provincial period 2010-2015. Retrieved October 25, 2015, from Ministry of Trade: http://www.kemendag.go.id/en/ec 
onomic-profile/indonesia-exportimport/growth-of-non-oil-and-gasexport-provincial.

Pambudy, N. M. (2011, March 04). Menguatkan degup jantung ekonomi. Retrieved October 25, 2015, from Kompas:

http://megapolitan.kompas.com/re ad/2011/03/04/02490645/twitter.co

$\underline{\mathrm{m}}$.

The Asia Foundation. (2008, April). Biaya transportasi barang angkutan, regulasi dan pungutan jalan di Indonesia. Retrieved October 24, 2015, from The Asia Foundation: https://asiafoundation.org/resourc es/pdfs/movinggoodslightbahasa.p df.

The World Bank. (2014, February 19). Mempercepat pergerakan container di pelabuhan utama Indonesia. Retrieved October 25, 2015, from The World Bank: http://www.worldbank.org/in/new s/feature/2014/02/19/moving- cargo-faster-in-indonesia-mainsea-port.

The World Bank. (2014, October 22). Reducing inequality in Indonesia. Retrieved October 24, 2015, from The World Bank: http://www.worldbank.org/en/cou ntry/indonesia/brief/reducinginequality-in-indonesia.

United Nations Conference on Trade and Development. (2007). Trade and development report: Regional cooperation for development. New York and Geneva: United Nations.

World Trade Organization. (2015). List of all regional trade agreements. Retrieved October 25, 2015 from World Trade Organization: http://rtais.wto.org/UI/PublicAllRT AList.aspx.

Wunderlich, J. U. (2012). Comparing regional organisations in global multilateral institutions: ASEAN, the EU and the UN. Asia Europe Journal, 10(2-3), 127-143. 